\title{
Either-Or: The Narrative of "Crisis" in Weimar Germany and in Historiography
}

\author{
Rüdiger Graf
}

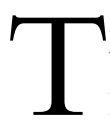

HE notion of "crisis" plays an important role in both the history of the Weimar Republic and the historiography on this period of German history. Modifying Max Horkheimer's famous dictum on the intrinsic connection between capitalism and fascism, one might even say that anyone who does not want to talk about "crisis" should remain silent about Weimar Germany. In the brief period between 1918 and 1933 Germany not only had to cope with the consequences of World War I and the Versailles Treaty, but also it was struck by two severe economic crises. Moreover, strong political forces relentlessly tried to overcome the unpopular democratic political system. After the National Socialists finally succeeded in overthrowing the republic, Weimar came to be conceptualized as the ill-born precursor of National Socialism, as the critical stage of German history before the establishment of a rule of terror that intentionally led into the most devastating war in human history. This perspective on the failure of Germany's first democracy stems largely from the dominance of National Socialism as a negative point of reference in historical as well as public debates in the Federal Republic.

At first glance, contemporaries in Weimar Germany seemingly confirmed this view. Writing about their own present they often diagnosed "crises." Between 1918 and 1933 more than 370 books were published bearing the term "crisis" in the title. While the number of these books remained relatively constant during the first years of the republic, it jumped in 1928 and then again in 1931-32. The number of the books diagnosing crises not only increased, but the range of crises also widened. In 1920 the German bibliography Deutsches Bücherverzeichnis referred under the term "crisis" only to economic crises, but by the beginning of the 1930s, it distinguished books concerning various crises, including agricultural, financial, industrial, economic, capitalist, revolutionary, religious, political, moral, general cultural, Germany's, and the world crisis, and also those addressing the solution to these crises. ${ }^{1}$ Even though the numbers of

\footnotetext{
${ }^{1}$ Deutsches Bücherverzeichnis. Eine Zusammenstellung der im deutschen Buchhandel erschienenen Bücher, Zeitschriften und Landkarten (Leipzig: Verlag für Buch- und Bibliothekswesen, 1924 and 1937), vol. 6, Halbband 1, and vol. 19, Halbband 2, 855 and 875. I thank Moritz Föllmer for long discussions on the "crisis" of Weimar Germany.
} 
articles in journals and newspapers concerning these various "crises" are more difficult to calculate, they seem to follow a similar pattern. ${ }^{2}$

In sum, the description in historical narratives of the Weimar Republic as a time of crisis appears intuitively plausible for three reasons. First, this era was the final critical stage before the dramatic course of German history entered into the "German catastrophe" around which most historians structure the grand narratives. Moreover, the development of economy, society, and politics showed signs we would today describe as crises. In economics, the Great Depression still serves as a paradigm case for crisis, as became obvious when commentators immediately compared the financial and economic collapse of 2008-09 to the economic downfall of 1929 and the early 1930s. Finally, the notion of "crisis" seems to have been all-pervasive in Weimar political and cultural discourses. Thus crisis suggests itself as a central term of interpretation. Probably the most elaborated and influential depiction of Weimar Germany as a period of crisis is Detlev Peukert's history of "the crisis of classical modernity." In the years between World War I and National Socialism, Peukert argues, modernity fully realized itself in social policy, technology, the natural and life sciences, art, and architecture while simultaneously encountering its first severe crisis. ${ }^{3}$

Newer studies inspired by Peukert's multifaceted work reject the hegemonic perspective of crisis and doom, describing the Weimar Republic rather as an open space of multiple developmental opportunities. ${ }^{4}$ Following this perspective, I will challenge and modify the still widely accepted notion of Weimar as a period of crisis. Reconstructing the ways in which the concept of "crisis" was actually used by the contemporaries, I will show that its simple transfer into historiography has been misguided: Weimar's crisis should neither be understood in a pessimistic sense as a prelude to National Socialism nor should "crisis" be used as a passepartout notion to explain other developments. This conclusion holds not only for the history of Weimar Germany. Rather than explaining historical processes and events by simply pointing at a crisis, convincing historical explanation must scrutinize the ways in which crises were diagnosed and used by various historical

\footnotetext{
${ }^{2}$ For my dissertation, from which large parts of this article are drawn, I scrutinized a representative sample of seven newspapers (Völkischer Beobachter, Neue preußische (Kreuz-)Zeitung, Deutsche Allgemeine Zeitung/Der Tag, Germania, Berliner Tageblatt, Vorwärts, Rote Fahne) and six journals (Die Tat. Monatsschrift für die Zukunft deutscher Kultur and after 1928, Die Tat. Monatsschrift zur Gestaltung neuer Wirklichkeit; Die Weltbühne; Die neue Zeit/Die Gesellschaft; Die Neue Rundschau; Die Deutsche Rundschau; Nationalsozialistische Monatshefte) as well as a great variety of articles from other periodicals. See Rüdiger Graf, Die Zukunft der Weimarer Republik. Krisen und Zukunftsaneignungen in Deutschland 1918-1933 (Munich: Oldenbourg, 2008).

${ }^{3}$ Detlev J. K. Peukert, Die Weimarer Republik. Krisenjahre der klassischen Moderne (Frankfurt am Main: Suhrkamp, 1987).

${ }^{4}$ Peter Fritzsche, "Did Weimar Fail?,” Journal of Modern History 68 (1996): 629-656. Wolfgang Hardtwig, ed., Ordnungen in der Krise. Zur politischen Kulturgeschichte Deutschlands 1900-1933 (Munich: Oldenbourg, 2007); for a review of the recent literature, see also Graf, Die Zukunft der Weimarer Republik, 13-27.
} 
actors. ${ }^{5}$ Otherwise we only reproduce contemporary assessments in uncritical ways and cannot properly assess the historical workings of crises. In order to establish these claims, I will first recapitulate the use of the notion of "crisis" in the historiography of the Weimar Republic and show how historians tend simply to transfer notions that were situated in past political conflicts into their analyses. After a brief etymological reflection on the notion of "crisis," I will then analyze how Germans actually used diagnoses of crisis between 1918 and 1933 . Finally, I will develop the consequences of this usage for the historiographical treatment of crisis in Weimar Germany and beyond.

\section{The "Crisis" in Weimar Historiography}

In the historiography on Weimar Germany the term "crisis" figures either as an explanandum or as an explanans - as something that has to be explained or as something that has explanatory value. ${ }^{6}$ On the one hand, many studies try to explain the occurrence of crises in fields such as the economy or the political system and, on the other, historians use these crises to explain other events and developments. Especially in the realm of economics, there have been many thorough studies scrutinizing the inflation, the often forgotten crisis of 1925-26, and the Great Depression. ${ }^{7}$ Using well-defined economic indicators, such as foreign trade, levels of production, exchange rates, and levels of unemployment, they try to determine the extent to which the German or even the world economy was in crisis. Historiographical debates focus on the causes of the various economic crises, their social consequences, and the evaluation of the political strategies

\footnotetext{
${ }^{5}$ Concerning the historiography of crises, see Jacob Burckhardt, "Die geschichtlichen Krisen," in Jacob Burckhardt, Weltgeschichtliche Betrachtungen. Über geschichtliches Studium. Historische Fragmente (Leipzig: Dieterich, 1985), 155-197; Gerhard Masur, "Crisis in History," Dictionary of the History of Ideas, 4 vols., ed. Philip P. Wiener (New York: Scribner, 1968), vol. 1, 589-596; Gottfried Haberler and Václav Holesovsky, "Konjunktur und Krise," in Sowjetsystem und demokratische Gesellschaft, vol. 3, ed. Claus D. Kernig (Freiburg, Basel, and Vienna: Herder, 1969), 814-847; Martin Jänicke, "Krisenbegriff und Krisenforschung," in Herrschaft und Krise. Beiträge zur politikwissenschaftlichen Krisenforschung, ed. Martin Jänicke (Opladen: Westdeutscher Verlag, 1973), 10-25; Knut Dohse, "Das politische System in der Krise. Modell einer revolutionären Situation," Politische Vierteljahrsschrift 12 (1971): 555-578; Rudolf Vierhaus, "Zum Problem historischer Krisen," in Historische Prozesse, Beiträge zur Historik, vol. 2, ed. Karl-Georg Faber and Christian Meier (Munich: dtv, 1978), 313-329; Randolph Starn, "Historians and 'Crisis,", Past and Present 52 (1971): 3-22; Wolfgang Behringer, "Die Krise von 1570. Ein Beitrag zur Krisengeschichte der Neuzeit," in Um Himmels willen. Religion in Katastrophenzeiten, ed. Manfred Jakubowski-Tiessen and Hartmut Lehmann (Göttingen: Vandenhoeck \& Ruprecht, 2003), 51-156, esp. 152-156.

${ }^{6}$ For a more detailed analysis, see Moritz Föllmer and Rüdiger Graf, eds., Die "Krise" der Weimarer Republik. Zur Kritik eines Deutungsmusters (Frankfurt am Main: Campus, 2005).

${ }^{7}$ See Theo Balderston, Economics and Politics in the Weimar Republic (Cambridge: Cambridge University Press, 2002); Gerald D. Feldman, The Great Disorder: Politics, Economics, and Society in the German Inflation 1924-1924 (New York and Oxford: Oxford University Press, 1993); Fritz Blaich, Die Wirtschaftskrise 1925/26 und die Reichsregierung. Von der Erwerbslosenfürsorge zur Konjunkturpolitik (Kallmünz: Laßleben, 1977); Charles P. Kindleberger, Die Weltwirtschaftskrise 1929-1939 (Munich: dtv, 1973).
} 
that were used to cope with the turbulences and downfalls, as well as the alternatives that might or might not have been available. ${ }^{8}$

In a similar vein, studies in the history of politics describe the political system of Weimar Germany as falling into a state of crisis at the beginning of the 1930s. Focusing on the period of the presidential cabinets from 1930 onward, governmental and party politics, and election results, these works try to reconstruct the series of events that seemed to narrow political options to the alternative between the declaration of a state of emergency (Staatsnotstand) and a cabinet under the guidance of Adolf Hitler. ${ }^{9}$ While in economic history there are clear and well-established criteria according to which crises can be defined and the term is employed, in the field of politics, however, the notion is often used more vaguely for any negative development. Even less clear is its use in the fields of social, cultural, or intellectual history. While it is rarely defined what a social, cultural, or intellectual crisis actually is, there are numerous studies that try to establish crises of certain social formations, such as the Bürgertum, the academic professions, and various milieus, or crises of the cultural situation and intellectual production as a whole. ${ }^{10}$

All of these studies that try to analyze "crises" in and of Weimar Germany share a negative and pessimistic understanding of the term. As it is customary today, they use "crisis" to signify processes of downward development, deterioration, and decay-if not doom. Times of "crisis" are depicted as turbulent periods that destabilize, perhaps even destroy, established structures and orders. Over the course of the twentieth century the original meaning of "crisis" as a "time of decision"- - to which I will return later-seems to have largely been lost. ${ }^{11}$ Even authors who try to retain the open notion of the term, distinguishing it

\footnotetext{
${ }^{8}$ Knut Borchardt, "Zwangslagen und Handlungsspielräume in der großen Weltwirtschaftskrise der frühen dreißiger Jahre," in Knut Borchardt, Wachstum, Krisen, Handlungsspielräume der Wirtschaftspolitik (Göttingen: Vandenhoeck \& Ruprecht, 1982), 165-182; Carl-Ludwig Holtfrerich, “Alternativen zu Brünings Wirtschaftspolitik in der Weltwirtschaftskrise," Historische Zeitschrift 235 (1982): 605-631; Albrecht Ritschl, Deutschlands Krise und Konjunktur 1924-1934. Binnenkonjunktur, Auslandsverschuldung und Reparationsproblem zwischen Dawes-Plan und Transfersperre (Berlin: Akademischer Verlag, 2002).

${ }^{9}$ Heinrich August Winkler, Weimar 1918-1933. Die Geschichte der ersten deutschen Demokratie (Munich: Beck, 1993), esp. 557-594; and Heinrich August Winkler, ed., Die deutsche Staatskrise 1930-1933. Handlungsspielräume und Alternativen (Munich: Beck, 1992). Concerning the crisis of parliamentarism in general, see Thomas Raithel, "Funktionsstörungen des Weimarer Parlamentarismus," in Die "Krise" der Weimarer Republik, ed. Föllmer and Graf, 243-266.

${ }^{10}$ See, for example, Hans Mommsen, "Die Auflösung des Bürgertums seit dem späten 19. Jahrhundert," in Bürger und Bürgerlichkeit im 19. Jahrhundert, ed. Jürgen Kocka (Göttingen: Vandenhoeck \& Ruprecht, 1987), 288-315; Konrad H. Jarausch, "Die Krise des deutschen Bildungsbürgertums im ersten Drittel des 20. Jahrhunderts," in Bildungsbürgertum im 19. Jahrhundert IV. Politischer Einfluß und gesellschaftliche Formation, ed. Werner Conze and Jürgen Kocka (Stuttgart: Klett-Cotta, 1989), 180-205; Walter Müller-Seidel, "Krisenjahre des Humanismus. Wissenschaften und Literatur in der Weimarer Republik," Jahrbuch der Akademie der Wissenschaften in Göttingen 1998 (1999), 73-134.

${ }^{11}$ See Edgar Morin, "Pour une crisologie,” Communications 25 (1976): 149-163, 149.
} 
from a purely negative meaning, equate Weimar's crisis with the latter sense of the term. "On the one hand, the crisis may appear to be terminal, proof that a certain way of life- say that of the Weimar Republic — is fatally diseased. On the other, crisis may be perceived as a temporary fever, possibly induced by a foreign virus, something to be dealt with, whereupon health and 'normality' - represented, say, by Swedish democracy — will be recovered." 12

Correspondingly, the historiography of Weimar Germany mainly construes its crises in the light of the following National Socialist rule as more or less important factors that destroyed the foundations of the republic and fostered the ascent of National Socialism. In many of these accounts, the crises in certain fields such as the economy do not appear as phenomena that need to be established. Rather, their occurrence is assumed and then used to explain developments and events in other fields, such as politics and culture. Even though no serious historian today reduces the causes of National Socialism to the Great Depression, many still consider the economic crisis an important causal factor for the rise of the NSDAP. ${ }^{13}$

Sometimes, as in Detlev Peukert's analysis, the various crises are lumped together, forming a "total crisis" of the years from 1930 to 1933. In HansUlrich Wehler's Deutsche Gesellschaftsgeschichte, this tightly knit web of crises (Krisenknäuel) figures as the principal cause for the destruction of the Weimar Republic. ${ }^{14}$ Once the crisis has become an all-encompassing phenomenon, a "crisis of the whole system of Weimar," as the National Socialist ideologue Alfred Rosenberg put it, it is used as an explanans, a causal factor that explains the history and the collapse of the republic as a whole. A crisis of these dimensions seems to be suitable not only to explain long-term structural changes, such as the transformation of German nationalism and the erosion of traditional milieus and party alliances. ${ }^{15}$ Almost every minor process and event seems to be understandable as a product of Weimar's crisis: as far as I can see, historians have referred to the crisis to explain specific phenomena such as the erosion of social formations and the transformation of gender roles, the results of parliamentary elections and the radicalization of German politics, the emergence of various sciences such as sociology and eugenics, specific intellectual outlooks and utterances of certain intellectuals, and even individual cultural products in literature and the

\footnotetext{
${ }^{12}$ Nina Witoszek and Lars Tragardh, "Introduction," in Culture and Crisis: The Case of Germany and Sweden, ed. Nina Witoszek and Lars Tragardh (New York and Oxford: Berghahn, 2002), 1-11, 4.

${ }^{13}$ See Eberhard Kolb's standard textbook Die Weimarer Republik (Munich: Oldenbourg, 2000), 107-124.

${ }^{14}$ Hans-Ulrich Wehler, Deutsche Gesellschaftsgeschichte, vol. 4, Vom Beginn des Ersten Weltkriegs bis zur Gründung der beiden deutschen Staaten 1914-1949 (Munich: Beck, 2003), 592f.

${ }^{15}$ Hans-Ulrich Wehler, "Radikalnationalismus. Erklärt er das 'Dritte Reich' besser als der Nationalsozialismus?," in Hans-Ulrich Wehler, Umbruch und Kontinuität. Essays zum 20. Jahrhundert (Munich: Beck, 2000), 47-64, 51; M. Rainer Lepsius, "Parteiensystem und Sozialstruktur. Zum Problem der Demokratisierung der deutschen Gesellschaft," in Deutsche Parteien vor 1918, ed. Gerhard A. Ritter (Cologne: Kiepenheuer \& Witsch, 1973), 56-80, 66.
} 
performing arts. ${ }^{16}$ In large parts of the historiography on Weimar Germany, "crisis" has become a catch-all concept that is used as an easy explanation when there is no space or interest for a more thorough analysis.

In this respect, it is astonishing to see how scholars smoothly transferred contemporary interpretations that arose from certain political conflicts into historical scholarship as factual descriptions of the past. In his famous analysis of the writings of antidemocratic intellectuals, for example, Kurt Sontheimer interpreted the renaissance of the idea of an "empire" as an expression of the widespread consciousness of crisis. In this argument, which he put forward in the early 1960s, Sontheimer explicitly reaffirmed Waldemar Gurian's position. As early as 1932, the Catholic intellectual Gurian had argued that the idea of an empire ("Reichsidee") endowed the "consciousness of crisis that dominated the German presence" with a positive sense. ${ }^{17}$ In the same year one of the leading journalists of the liberal Berliner Tageblatt, Rudolf Olden, edited a book on popular religion and belief in miracles entitled Propheten in deutscher Krise (Prophets in German Crisis). ${ }^{18}$ Perceiving a dominance of the miraculous - he maintained there were 3,000 wizards practicing in Berlin alone - and a general shift from the "rational to the irrational" in contemporary German politics, Olden saw crisis as the main source for these developments: "In crisis, rationality is pushed aside; its weapons that used to be sharp are suddenly blunt." ${ }^{19}$ Fifty years later, Ulrich Linse developed the same argument in his analysis of the occurrence of the socalled "bare-footed prophets" who became popular in Germany in the 1920s. For the first chapter, Linse even used almost the same title as Olden: Propheten in der Krise (Prophets in the Crisis). In the introduction to Gesellschaftskrise und Narrenparadies, Hagen Schulze agreed with Linse's and Olden's explanation of the "Inflationsheiligen" as a product of the economic conditions in the early 1920s and the Great Depression. ${ }^{20}$

Accusing political opponents of irrationality and reducing their views to the economic conditions of their production was very common among liberals and

\footnotetext{
${ }^{16}$ This is a very common theme in Weimar historiography. See Paul Weindling, Health, Race, and German Politics between National Unification and Nazism 1870-1945 (Cambridge: Cambridge University Press, 1989), 339; Norbert Bolz, Auszug aus der entzauberten Welt. Philosophischer Extremismus zwischen den Weltkriegen (Munich: Fink, 1989), 8; Michael Grimminger, Revolution und Resignation. Sozialphilosophie und die geschichtliche Krise im 20. Jahrhundert bei Max Horkheimer und Hans Freyer (Berlin: Duncker und Humblot, 1995), 24; Stefan Vogt, Nationaler Sozialismus und Soziale Demokratie. Die sozialdemokratische Junge Rechte 1918-1945 (Bonn: Dietz, 2006), 99.

${ }^{17}$ Kurt Sontheimer, "Die Idee des Reiches im politischen Denken der Weimarer Republik," Geschichte in Wissenschaft und Unterricht 13 (1962): 205-221, 220; Walter Gerhart (Pseudonym of Waldemar Gurian), Um des Reiches Zukunft. Nationale Wiedergeburt oder politische Reaktion? (Freiburg: Herder, 1932), 125.

${ }^{18}$ Rudolf Olden, ed., Propheten in deutscher Krise. Das Wunderbare oder die Verzauberten (Berlin: Rowohlt, 1932).

${ }^{19}$ Ibid., 16, 20

${ }^{20}$ Ulrich Linse, Barfüßige Propheten. Erlöser der zwanziger Jahre (Berlin: Siedler Verlag, 1983), 10-20.
} 
"republicans of reason" (Vernunftrepublikaner) during the 1920s. As Thomas Mann maintained in his famous "German Address" (Deutsche Ansprache. Ein Appell an die Vernunft) in Berlin in 1930, the wave of the economic crisis had stirred up "political passions." 21 At the beginning of 1931 Theodor Wolff, the editor of the Berliner Tageblatt, argued that the psychosis caused by the crisis was almost more devastating than the psychosis that had been caused by the war. In his view, it led people in their "holy simplicity" and longing for religious sentiments to believe in the National Socialist "doctrine of salvation" and to engage in its dubious pseudo-religious practices. ${ }^{22}$ In general, moderate intellectuals argued against their opponents on the radical right and left for political reason as opposed to irrational sentiments. But even in the left-wing Weltbühne, for example, Carl von Ossietzky attacked his political adversaries, the revolutionaries from the right who published in the journal Die Tat, suggesting that they had developed "apocalyptic sentiments" as soon as the crisis started. ${ }^{23}$

Similar arguments have often been reproduced in historiography, not least because they were predominantly used by republican intellectuals against their extremist counterparts. From this perspective, crises destroyed formerly secure expectations of the future, thereby creating insecurity and pessimistic sentiments among the people. Intellectuals allegedly overcompensated for this loss of security, producing apocalyptic fears or utopias and visions of stable orders, and thereby futurizing political, social, and economic discourses. ${ }^{24}$ This argument can be used for long-term processes and general characteristics of modernity as well as for short-term historical constellations. For example, Thomas Nipperdey determined crises as the main causes for the development of utopian schemes and ideas that characterized modern times. ${ }^{25}$ Focusing on the brief period from 1914 to 1924 and the city of Munich, Martin Geyer argued that the flourishing "social, political, and cultural experiments [. . .], utopias and doctrines of salvation" were "answers to the crisis of the present."26

\footnotetext{
${ }^{21}$ Thomas Mann, Deutsche Ansprache. Ein Appell an die Vernunft. Rede, gehalten am 17. Oktober 1930 im Beethovensaal zu Berlin (Berlin: Fischer, 1930), 9.

${ }^{22}$ Theodor Wolff, “Besseres neues Jahr! 'Salve!' mit Vorbehalt," Berliner Tageblatt und HandelsZeitung, Morgenausgabe, Jan. 1, 1931.

${ }^{23}$ Carl von Ossietzky and Thomas Murner, "Zehrer und Fried," Die Weltbühne 28, Halbband 2 (1932): 771-775, 771. Noting this as a general tendency, see Carl Steuermann, "Der Mensch auf der Flucht," Die Neue Rundschau, vol. 43, Halbband 1 (1932): 289-300, 296.

${ }^{24}$ Detlev J. K. Peukert, Max Webers Diagnose der Moderne (Göttingen: Vandenhoeck \& Ruprecht, 1989), 66; Luise Schorn-Schütte, "Religion, Kultur und Staat. Deutungsmuster aus dem Krisenbewußtsein der Republik von Weimar. Eine Einleitung," Zeitschrift für Historische Forschung, Beiheft 23 (1999): 7-24, 7; Klaus Vondung, Die Apokalypse in Deutschland (Munich: dtv, 1988), 245.

${ }^{25}$ Thomas Nipperdey, "Die Funktion der Utopie im politischen Denken der Neuzeit," Archiv für Kulturgeschichte 44 (1962): 357-378, 362.

${ }^{26}$ Martin H. Geyer, Verkehrte Welt. Revolution, Inflation, Moderne. München 1914-1924 (Göttingen: Vandenhoeck \& Ruprecht, 1998), 19.
} 
In the widely accepted explanations of intellectual transformations by reference to crisis, it often remains unclear how exactly the crisis became causally relevant. Moreover, historians tend to neglect the historical roots of the argumentative scheme they use. Its origin and widespread acceptance in past political discourses, however, might cast doubt on its validity and explanatory value. Apart from this polemical usage, there are many other examples in which contemporary understandings of crises and their causal workings have been adopted into historical scholarship: many historians of the social sciences still share Hans Freyer's definition of sociology as a science of crisis (Krisenwissenschaft), that is, an intellectual reaction to the crisis of society trying to overcome it. ${ }^{27}$ Similarly, Ernst Troeltsch's diagnosis of a "crisis of historicism" that transformed conceptions of time as well as historical consciousness after World War I still has high currency among cultural historians. ${ }^{28}$ All of these historical assessments, however, understand "crisis" as an explanatory concept that signifies an external force with causal powers that exert a negative influence on an otherwise stable situation or even a positive development.

\section{Defining "Crises”}

The etymology of the term "crisis" seems to contradict its common usage in historiography. "Crisis" and the German "Krise" stem from the Greek $\kappa$ píøı or "krisis," which signified neither a negative development nor a precursor of secured doom, but rather the moment of decision in which the future remained open and two alternative developments were possible. Denoting the moment in which a decision was about to occur, the Greek "krisis" still combined the later separate notions of an objective crisis and subjective critique, as Reinhart Koselleck has shown in his classic history of the concept. ${ }^{29}$ This etymology already indicates that the notion of "crisis" is more closely connected to human perception than other historiographical terms. Relating current developments to future options, observers constitute crises when they try to integrate complex processes into a narrative structure. No matter how bad, disorderly,

\footnotetext{
${ }^{27}$ Hans Freyer, Soziologie als Wirklichkeitswissenschaft. Logische Grundlagen des Systems der Soziologie (Leipzig and Berlin: Teubner, 1930), 165f.; Paul Nolte, Die Ordnung der deutschen Gesellschaft. Selbstentwurf und Selbstbeschreibung im 20. Jahrhundert (Munich: Beck, 2000), 16, 22, and 129; Wolf Lepenies, "Geschichte und Anthropologie. Zur wissenschaftshistorischen Einschätzung eines Disziplinenkontakts," Geschichte und Gesellschaft 1 (1975): 325-343.

${ }^{28}$ Gideon Reuveni, "Geschichtsdiskurs und Krisenbewußtsein. Deutsche Historiographie nach dem Ersten Weltkrieg," Tel Aviver Jahrbuch für deutsche Geschichte 25 (1996): 155-186, 156; Wolfgang Hardtwig, "Die Krise des Geschichtsbewußtseins in Kaiserreich und Weimarer Republik und der Aufstieg des Nationalsozialismus," Jahrbuch des Historischen Kollegs 7 (2001): 47-76.

${ }^{29}$ Reinhart Koselleck and U. Schönpflug, "Krise," in Historisches Wörterbuch der Philosophie, vol. 4, ed. Joachim Ritter and Karlfried Gründer (Basel: Schwabe, 1976), 1235-1245, 1235; Reinhart Koselleck, "Krise," in Geschichtliche Grundbegriffe, vol. 3, ed. Otto Brunner, Werner Conze, and Reinhart Koselleck (Stuttgart: Klett-Cotta, 1982), 617-650.
} 
and turbulent events and processes at a certain time are, they become a crisis only by relating them to a past development and projecting two different paths into the future, thereby defining the present as the critical moment of decision. Understood in this way, the constitution of crisis presupposes an observer, whether a contemporary with his or her particular interests or a historian trying to depict a turning point in his or her narrative.

A central element of the narrative of crisis is its existential dimension, which becomes obvious in its classical use as a technical term in medicine or the military. According to Hippocrates, in medicine "crisis" signifies the short time during which the existential question of the patient's life or death is decided, usually occurring on certain days of the disease. In the military, crisis refers to the brief period of a battle during which the combatants seek a decision through the exertion of all forces. Hence the concept of "crisis" combines diagnostic and prognostic elements. Defining the present as a time of decision, the crisis has three implications for the future. First, there will be a time of further insecurity in which two existentially different possibilities are equally possible. Second, after the decision, ending this insecurity, either a good or a bad future will be realized. Third, "crisis" has an active element, defining the present as a time to act in order to prevent the undesirable and realize the desirable option. ${ }^{30}$

Therefore diagnoses of crises are never simple descriptions of a past reality. Their intrinsic connections to possible future developments relate crises to observers and their expectations of the future or to historians and their narrative strategies. This constitution of crisis in the eye of a beholder has important implications for the treatment of crises in historiography. Rather than depicting crises as causal factors that influenced political, cultural, or intellectual developments, we have to ask who defined the crisis, what exactly was perceived as constituting the critical decision, and which strategies of action were implied. Not only were actual historical constellations decisive for the occurrence of crises, but also people's expectations and political interests. Only after a careful examination of the intellectual outlooks and practices that constitute the "crisis" can its historical consequences be assessed. Moreover, historians need to reflect on their own narrative and dramatic strategies as well as their assumptions about the course of history in general when referring to a crisis as either an explanans or an explanandum.

These etymological considerations would be futile if they had no connection to the use of the term "crisis" in Weimar Germany. But, contrary to the dominant usage today, in Weimar Germany its original etymology seems to have been well known. As a Germanized "Krisis," the Greek term was still widely used: almost

\footnotetext{
${ }^{30}$ Ibid.; and Reinhart Koselleck, "Some Questions Concerning the Conceptual History of 'Crisis,", in Culture and Crisis: The Case of Germany and Sweden, ed. Nina Witoszek and Lars Tragardh (New York and Oxford: Berghahn, 2002), 12-23.
} 
half of the books and articles on crisis mentioned above bore "Krisis" instead of "Krise" in the title. The great German encyclopedias of the late nineteenth and early twentieth century even lacked an entry under the heading "Krise" but contained short articles on "Krisis." Those entries mostly treated the medical use of the term and only referred to "trade-crisis" ("Handelskrise") as a transferred usage that received an entry of its own. Both Brockhaus's and Meyer's encyclopedias defined "Handelskrisen" as "shocks and disturbances" ("Erschütterungen" and "Störungen") of the production and exchange of goods, usually interrupting a fast economic boom that might have had various causes. While trade crises and their negative consequences had to be avoided, medical crises even had a positive and productive meaning. Meyer's Encyclopedia defined 'Krisis (Greek, 'Krise,' 'judgment,' 'decision') [as] the outcome of a disease in convalescence if it occurs fast and completely, while the slow removal of a disease is called Lysis. But the concept of crisis also implies that the outcome in convalescence is accompanied by increased workings of the secreting organs." 31 While the old Hippocratic idea that each disease had critical days that decided its outcome was rejected, crises were conceived of as often turbulent processes in which a disease was overcome and the patient's health was restored.

In the second half of the twentieth century the definition of the medical "Krisis" opened up again, signifying either the high point of a disease, its critical phase, or its outcome toward convalescence, especially integrating psychological crises. ${ }^{32}$ The economic and common-language "Krise" in turn acquired a broader semantic extension and definitional depth. As early as 1927, Meyers Lexikon devoted separate articles on the medical "Krisis," the economic "Krise," "Krisenfürsorge," and "Krisenversicherung." ${ }^{3}$ In the late nineteenth and early twentieth centuries research on economic crises as breakdowns of economic growth processes flourished widely not only among Marxists. Economists tried to integrate crises into the comprehensive study of business cycles ("Konjunkturtheorie"), assuming that the sudden breakdowns of economic booms and the destruction of economic production and trade were understandable only in correlation to the movement of the economic trend as a whole and were explicable only in that connection. ${ }^{34}$ Thus in the field of economics, on a lexical level, "crisis" was clearly defined in Weimar Germany as the temporary interruption of an otherwise upward development. In medicine, "crisis" even

\footnotetext{
${ }^{31}$ Meyers Großes Konversationslexikon, 6th ed., vol. 11 (Leipzig and Vienna: Bibliographisches Institut, 1908), 700; see also ibid., vol. 8 (1908), 733-735; Brockhaus' Konversationslexikon, 14th ed., vol. 10 (Leipzig, Berlin, and Vienna: Brockhaus, 1894), 743, and vol. 8 (1893), 745.

${ }^{32}$ Meyers Enzyklopädisches Lexikon, 9th ed., vol. 14 (Mannheim, Vienna, and Zurich: Bibliographisches Institut, 1975), 372; Brockhaus Enzyklopädie, 18th ed., vol. 12 (Mannheim: Brockhaus, 1990), 517.

${ }^{33}$ Meyers Lexikon, 7 th ed., vol. 7 (Leipzig: Bibliographisches Institut, 1927), $206 f$.

${ }^{34}$ Ibid., 206.
} 
signified the temporarily stressful, but ultimately positive development toward the recovery of health. Lexical definitions as well as etymological considerations, however, do not determine the actual meaning of concepts that can always be used in multiple ways assuming various meanings. Hence the meaning of "crisis" and the significance of its frequent use in the ubiquitous discourses of crises can only be determined by looking at how contemporaries actually used the term.

\section{Contemporary Constructions of Crises in Weimar Germany}

Even a short glance at diagnoses of crises from various political and intellectual backgrounds suggests an open if not optimistic understanding of the term. ${ }^{35}$ For example, in the turbulent early years of the republic during the inflation, the philosopher Arthur Liebert declared that a time without crises would be a dead time, and at the high point of the Great Depression, the architect Erich Mendelsohn emphasized the creative sense of the term crisis. ${ }^{36}$ At the same time, when the German economy was moving downward with accelerating speed, crises were defined in the Weltbühne as the origins of creativity (the "Urschöpferische"). While these authors emphasized the creative potential of the crisis, Erwin Ritter, writing in the journal Die Tat, doubted its existence. Pointing out the intellectual constructions involved in definitions of crises, he suggested, "The present crisis is not a natural process. Every flood, epidemic, or forest fire is more real than what fills the newspapers today." 37 The constructivist element in the political crisis was also clear to liberal observers: they saw the breakdown of the Great Coalition in 1930 not as an impersonal or deterministic process, but as the product of the activities of politicians from the German People's Party (DVP) who created crises ("Krisenmacher") and strategically pursued a politics of catastrophe ("Katastrophenpolitik"). ${ }^{38}$

Actually, it is difficult to find any prominent author, politician, intellectual, or journalist in Weimar Germany who publicly used the notion of crisis in a pessimistic or even fatalistic sense. All of the contemporary authors, at least, left it undecided in which way the crisis would be resolved, if the old or the new-

\footnotetext{
${ }^{35}$ Peter Fritzsche, "Landscape of Danger, Landscape of Design: Crisis and Modernism in Weimar Germany," in Dancing on the Volcano: Essays on the Culture of the Weimar Republic, ed. Thomas W. Kniesche and Stephen Brockmann (Columbia: Camden House, 1994), 29-46, 42; Müller-Seidel, "Krisenjahre des Humanismus," $77 \mathrm{f}$.

${ }^{36}$ Erich Mendelsohn, Der schöpferische Sinn der Krise. Vortrag, gehalten auf dem Kongreß des Internationalen Verbandes für kulturelle Zusammenarbeit in Zürich Mai 1932 (Berlin: B. Cassirer, 1932); Arthur Liebert, Die geistige Krisis der Gegenwart, 2nd ed. (Berlin: Pan-Verlag Rolf Heise, 1923).

${ }^{37}$ Anton Kuh, "Grabrede auf einen Intendanten," Die Weltbühne 26 (1930): 97-100; Erwin Ritter, "Die große Stadt," Die Tat 23 (1931): 632-637, 632f.

${ }^{38}$ Modris Eksteins, The Limits of Reason: The German Democratic Press and the Collapse of Weimar Democracy (Oxford: Oxford University Press, 1975), 194.
} 
and in their view good- powers held an advantage and would succeed. ${ }^{39}$ Most of them considered the "horrible, low state of the present" not as the end, but believed that the current "Krisis" was a state of "extremely severe, confused fermentation," heading toward a near, light, and better future..$^{40}$ Even authors who painted the crisis in the darkest colors, as, for example, the former elites of the Kaiserreich now leaning toward the German National People's Party (DNVP) or the monarchists, always left open the possibility of a positive solution, constructing the present as a time of decision in which all feelings from hope and doubt to anxiety were reasonable. ${ }^{41}$ Thus, the crisis never appeared to be the precursor of certain doom, but its diagnosis was rather a call to action. Characteristically, the clinical metaphors that those authors who were critical of Germany's political and economic situation used frequently to describe their present corresponded to the lexical definition of a medical "Krisis"; the diseases were never fatal, but were always illnesses that could be overcome if certain cures were taken or that were only fevers announcing the future recovery. ${ }^{42}$

To substantiate this first impression one must not only look at diagnoses of crises alone, but also take into consideration the broader discourses about the future in Weimar Germany in general. Because of its prognostic implications, "crisis" was one way among others to talk about the future, and its popularity can only be explained with respect to the principal structures of Weimar's horizon of expectation. Newspapers and political and cultural journals publicly expressed visions of the future as did freestanding publications ranging from short political pamphlets to utopian novels to scientific prognoses. Analyzing a representative sample of these publications from all parts of the political spectrum, focusing not so much on the contents of the visions, but rather on the attitudes expressed in certain ways of talking about the future, one can determine a couple of general tendencies. These appropriations of the future cut through the classical division lines of the political spectrum, laying the common grounds on which the vigorous political and cultural conflicts of the Weimar Republic could occur. ${ }^{43}$

\footnotetext{
${ }^{39}$ Reinhard Buchwald, "Die Bildung im Zeitalter der Kulturkrise," Die Tat 16, Halbband 1 (1924/ 25): 1-6, 2 .

${ }^{40}$ Fritz Tögel, "Ziel und Weg. An die Suchenden und Lichtfreunde aller Stände des deutschen Volkes," Neues Land 1 (1921): 1f., 1.

${ }^{41}$ See, for example, Paul Conrad, "Zum neuen Jahr," Neue Preußische Zeitung, Morgenausgabe, Dec. 31, 1922. See also Arne Hofmann, "Wir sind das alte Deutschland, das Deutschland, wie es war." Der "Bund der Aufrechten" und der Monarchismus in der Weimarer Republik (Frankfurt am Main et al.: Akademie Verlag, 1998), 74-77; Rüdiger Graf, "Die 'Krise' im intellektuellen Zukunftsdiskurs der Weimarer Republik," in Die "Krise” der Weimarer Republik, ed. Föllmer and Graf, 77-106, esp. 82-91.

${ }^{42}$ Moritz Föllmer, “Der 'kranke Volkskörper.' Industrielle, hohe Beamte und der Diskurs der nationalen Regeneration in der Weimarer Republik," Geschichte und Gesellschaft 25 (2001): 41-67, 51.

${ }^{43}$ See Graf, Die Zukunft der Weimarer Republik, 33-38. For a list of journals and newspapers, see footnote 2 .
} 
Since elements of the discourses about the future in Weimar Germany converged in the notion of "crisis," the term neatly captured basic tendencies of the horizon of expectation and gained widespread acceptance and popularity. Despite early republican efforts to conceptualize the Weimar Republic itself as the fulfillment of former visions and utopias, the "new time" remained a concept of expectation throughout its existence. Since many contemporary intellectuals and politicians expected the coming of a "new man" and a "new time," they conceptualized their present as a "Zeitenwende," a fundamental turn of times or an epochal change between different worlds. As the present was seen as a period of turbulence, visions of break and renewal became far more popular compared to expectations of continuous development - a process that further accelerated during the years of the Great Depression. ${ }^{44}$ Opinions differed between moderate and radical authors about how long upheavals of the "Zeitenwende" might last, but because of its unpleasant consequences, short-term visions looked more attractive than long-term expectations. Particularly attractive, however, were rhetorical figures that located the future as already existing in the present, whether in various life forms, faraway countries, or political or social groups. ${ }^{45}$ In this way, visions of the future could be depicted not only as desirable but also as realizable, because the future had already begun and was about to be fully realized. Its realization, however, depended on people's activity: in general, passivity and even fatalism were not options for Weimar intellectuals, but authors of all political backgrounds shared an activist tendency, believing in the opportunity of creative activity to change the path of future development. This optimistic belief in the malleability of fundamental political, social, and economic conditions received greater urgency considering the present as a "Zeitenwende" in which decisions for future generations had to be made. ${ }^{46}$

At first glance, this activist and optimistic depiction of discourses about the future in Weimar Germany seems to contradict the widespread characterization of Weimar as an era of pessimism or at least of contemporaries as being drawn between pessimism and fatalism on the one hand, and delusions of feasibility on the other. ${ }^{47}$ Indeed pessimistic scenarios were widespread within the political and intellectual debates. Yet they never became dominant or all-pervasive, but were always circumscribed. Either pessimistic scenarios concerned only certain subsystems, such as capitalism, liberalism, and democracy (which were rejected), or they were viewed as temporary downward developments, which sooner or later would end and usher in an ascent. Particularly attractive was the use of pessimistic scenarios as one element within the rhetorical construction of a mutually

\footnotetext{
${ }^{44}$ Ibid., 135-204.

${ }^{45}$ Ibid., 205-270; Rüdiger Graf, "Anticipating the Future in the Present-'New Women' and Other Beings of the Future in Weimar Germany," Central European History 42, no. 4 (2009): 1-27.

${ }^{46}$ Graf, Die Zukunft der Weimarer Republik, 271-328.

${ }^{47}$ Peukert, Max Webers Diagnose, 57.
} 
exclusive alternative for Germany's future development. The connection of existential alternatives with an exclusive "either-or," which is also an essential element within the construction of crises, was immensely popular in Weimar Germany. Pamphleteers in particular used the formula for catchy titles that were also slogans, in which few words simultaneously expressed a mortal threat, a necessary decision, and the possibility of betterment. ${ }^{48}$

While intellectual historians of Weimar Germany have noted the popularity of decisionism in philosophy and jurisprudence, and especially among right-wing intellectuals such as Carl Schmitt, Ernst Jünger, and Martin Heidegger, its broader dissemination has only rarely been under scrutiny. ${ }^{49}$ Following Hannah Arendt, the reduction of a complex reality to the manichaean distinction between a good or a bad future has often been seen as a characteristic element of totalitarian thinking. ${ }^{50}$ And indeed, apart from all differences of their political ideologies and practices, communists and National Socialists used similar rhetorical strategies and were almost obsessed with the construction of mutually exclusive alternatives. In the tradition of Friedrich Engels's slogan "socialism or barbarism," early German communists made frequent use of radical dichotomies. At the end of World War I Rosa Luxemburg described the political situation as follows: "We are standing, as Friedrich Engels predicted . . f forty years ago, before a choice: either triumph of imperialism and destruction of all culture, as in ancient Rome, depopulization, desolation, degeneration, a great graveyard. Or victory of

\footnotetext{
${ }^{48}$ See, for example, Otto Dibelius, Zukunft oder Untergang (Berlin: Christl. Zeitschriftenverlag, 1922); Heinz Oskar Ziegler, Autoritärer oder totaler Staat (Tübingen: Mohr, 1932); Arno Franke, Nach Eden oder nach Golgatha? Eine ernste Frage an Deutschlands Arbeiterschaft. Mit einem Geleitwort von Konrad Haenisch (Berlin: Firn-Verlag, 1919); Erwin Barth, Ruin oder Aufstieg (Berlin: Arbeitsgemeinschaft, 1919); Albert Vögler, Untergang oder Aufbau; Sowjetstern oder Hakenkreuz? Deutschlands Weg-Deutschlands Rettung. Ein Waffengang zwischen Faschisten und Kommunisten (Berlin: Vereinigte Internationale Verlagsanstalt, 1923); Hermann Remmele, Sowjetstern oder Hakenkreuz? Die Rettung Deutschlands aus der Youngsklaverei und Kapitelknechtschaft (Berlin: Internationaler Arbeiter-Verlag, 1930); Otto Bangert, Gold oder Blut. Wege zur Wiedergeburt aus dem Chaos (Munich: Eher-Verlag, 1927); Emil Berg, Des deutschen Volkes Schicksalsweg. Diktatur oder Untergang (Leipzig: Hillmann, 1928); Paul Rohrbach, Deutschland! Tod oder Leben? (Munich: Bruckmann, 1930); Gerhard Eschenhagen, Entscheidung. Bekenntnis eines jungen Deutschen (Berlin-Steglitz: Hendriock, 1931); Wilfried Otten, Schwarz-rot-gold oder Hakenkreuz? Ein Buch aus Kameradschaft, eine Aufklärung und ein Wegweiser (Heidenheim an der Brenz: Rees, 1931); Magdalene von Tiling, Konservativ oder liberal? Zukunft oder Untergang (Berlin: Deutschnationale Schriftenvertriebsstelle, 1930); Anonymous, Entweder Hunger, Faschismus, Krieg oder Brot, Freiheit, Frieden (Berlin: Internationaler Arbeiter-Verlag, 1931). See also Heinz Pol, Entweder-Oder. Ein politischer Roman (Berlin: Deutscher Bücherschatz, 1930).

${ }^{49}$ Christian Graf von Krockow, Die Entscheidung. Eine Untersuchung über Ernst Jünger, Carl Schmitt, Martin Heidegger (Stuttgart: Enke, 1958); or Michael Makropoulos, "Krise und Kontingenz. Zwei Kategorien im Modernitätsdiskurs der klassischen Moderne," in Die "Krise" der Weimarer Republik, ed. Föllmer and Graf, 45-76.

${ }^{50}$ Andreas Wirsching, Vom Weltkrieg zum Bürgerkrieg. Politischer Extremismus in Deutschland und Frankreich 1918-1933/39. Berlin und Paris im Vergleich (Munich: Oldenbourg, 1999), 10.
} 
socialism." ${ }^{11}$ The programs and political slogans of the Spartacists used similar formulations, and the Communists reiterated them throughout Weimar Germany. For example, in 1931 Hermann Remmele declared in a speech before the Communist Party's Central Committee, "You have the choice, to die through bankrupt capitalism, or to fight and live through the victory of socialism, through Soviet-Germany." 52

Structurally quite similar, the National Socialists always depicted an alternative between Germany's ascendancy to world power, on the one hand, and its "racial decline" and subsequent total annihilation on the other. If the current situation were to continue or the communists assumed power, Adolf Hitler predicted at the end of 1932, this would lead to "an endless time of barbarianism, a decay of mankind with unbelievable misery, and centuries of regress." ${ }^{53}$ In the middle of the 1920s, the National Socialists already saw the German people in an existential fight confronted "with the unavoidable decision, produced by the cruel coercion of history, to perish or to fight for its life." ${ }^{4}$ If the people chose the latter option and followed the National Socialist lead, the promise was a light future of a renewed national community in a powerful "Reich." 55

The rhetorical figure of the exclusive dichotomy was so popular that it even turned into a substantialized "either-or" that seemed to be able to confront people and have historical power of its own. In the description of his alleged "decision" to become a "politician," Adolf Hitler claimed in Mein Kampf that there was "no making deals with the Jew, but only the hard either-or." 56 In 1927 Alfred Rosenberg saw Germany and all European states standing before an "either-or." 57 This substantialized "either-or" also appeared in the writings of so-called "conservative revolutionaries," who, like Ernst Niekisch, announced an end to all "as-well-as-systems," cultivating a pathos of decisionism. ${ }^{58}$ But also on the political left, prominent figures, such as Rosa Luxemburg, constructed a

${ }^{51}$ Junius (Pseudonym of Rosa Luxemburg), Die Krise der Sozialdemokratie, 2nd ed. (Zurich: Union, 1917), 13.

${ }^{52}$ Hermann Remmele, Kapitalistischer Zusammenbruch in Deutschland-Sozialistischer Aufbau in der Sowjetunion. Rede auf dem Plenum d. ZK d. KPD am 14. u. 15. Mai 1931 (Berlin: Internationaler Arbeiterverlag, 1931); Anonymous, "Was will der Spartakusbund," Die Rote Fahne, Dec. 14, 1918; Rosa Luxemburg, "Aufruf an die Proletarier aller Länder,” Die Rote Fahne, Nov. 25, 1918.

${ }^{53}$ Adolf Hitler, "Neujahrsbotschaft," Nationalsozialistische Parteikorrespondenz, Dec. 31, 1932.

${ }^{54}$ Otto Bangert, "Volksstaat," Völkischer Beobachter, Dec. 31, 1926. See also Anonymous, “Neujahr," Münchener Beobachter. Völkischer Beobachter, Jan. 1, 1926.

${ }^{55}$ Concerning the propaganda of the NSDAP and the worldviews of its leading figures, see Gerhard Paul, Der Aufstand der Bilder. Die NS-Propaganda vor 1933 (Bonn: Dietz, 1990); and Frank-Lothar Kroll, Utopie als Ideologie. Geschichtsdenken und politisches Handeln im Dritten Reich (Paderborn et al.: Schöningh, 1998).

${ }^{56}$ Adolf Hitler, Mein Kampf, vol. 1, Eine Abrechnung, 3rd ed. (Munich: Franz Eher Nachfolger, 1928), 217.

${ }^{57}$ Alfred Rosenberg, Der Zukunftsweg einer deutschen Außenpolitik (Munich: Eher Verlag, 1927), 142.

${ }^{58}$ Ernst Niekisch, Entscheidung (Berlin: Widerstands-Verlag, 1930), 96. 
"dilemma of world history, an either-or, the scales of which were trembling before the decision to be made by the class-conscious proletariat." 59 Even more independently minded leftist intellectuals such as Kurt Hiller declared in the 1920s that at present there was only a "yes or no, an either-or" and saw the "either-or lying at all ends and corners of society, ready to jump."60

Using these constructions of radical dichotomies over and over again, radical authors on the right and left narrowed down the complex political world to two exclusive alternatives that were existentially different. Thereby, they defined the present as the time of decision trying to motivate people to become active. The greater the difference between the desirable and the undesirable option, the deeper was the crisis and the greater the sense of urgency (i.e., the necessity to act). Radical politicians and intellectuals who wanted to realize a utopian scheme, therefore, needed to paint the present in the darkest colors to justify the most radical actions toward the implementation of their plans. To deepen the sense of the crisis, they extended its spatial and temporal scope, emphasizing its worldwide dimension and its historical significance by likening it to such transformations as the Renaissance or even by purporting its singularity. At the beginning of 1932, for example, Adolf Hitler declared that the "world approaches a decision that often occurs only once in a millennium."61 And for the Spartacists, on the other side, the "realization of the socialist order of society" was "the grandest task that ever fell on any class and any revolution in world history."62

Even though in Weimar Germany political extremists from the left and right used radical dichotomies most often and obsessively, a broader analysis of the political and intellectual utterances casts doubts on the connection of the "either-or" with totalitarian modes of thinking. Horror-scenarios of future developments and their juxtapositions to optimistic visions were far more widespread and used by politicians of all parties and intellectuals of various convictions. ${ }^{63}$ In 1929 the Federation of German Industry, for example, saw the German economy at an essential crossroads and issued a memorandum under the title "Ascent or Decline." 64 And only at first glance did the sociologist Franz Oppenheimer

\footnotetext{
${ }^{59}$ Junius, Die Krise der Sozialdemokratie, $13 \mathrm{f}$.

${ }^{60}$ Kurt Hiller, Der Aufbruch zum Paradies (Munich: Kurt Wolff Verlag, 1922), 144. See also Heinrich Mann, "Das Bekenntnis zum Übernationalen," Die Neue Rundschau 43, Halbband 2 (1932): 721-746, 721.

${ }^{61}$ Adolf Hitler, "Neujahrsaufruf," Völkischer Beobachter, Jan. 1 and 2, 1932. See also Herbert von Voß, "Zeitenwende," Nationalsozialistische Monatshefte 3 (1932): 492-496.

${ }^{62}$ Anonymous, "Was will der Spartakusbund?," Die Rote Fahne, Dec. 14, 1918.

${ }^{63}$ Florian Stadel, Die letzten freien Reichstagswahlen 1930/32 im Spiegel der deutschen Presse (Aachen: Shaker, 1997), 227; Graf, Die Zukunft der Weimarer Republik, 186-201.

${ }^{64}$ Reichsverband der Deutschen Industrie, Aufstieg oder Niedergang? Deutsche Wirtschafts- und Finanzreform 1929. Eine Denkschrift des Präsidiums des Reichsverbandes der deutschen Industrie (Berlin: Selbstverlag, 1929).
} 
supersede the logic of this radical dichotomy when he entitled his depiction of an economic third way between fascism and communism "Neither this-nor that." His description of the present was full of dichotomies that constructed the present as a time of an existential decision: "World history: the fight between freedom and lack of freedom [Unfreiheit]. First victory: liberation of the human; second, definitive victory: liberation of the earth. But there is no victory without a fight. Consider: it is five minutes to twelve, the manometer points at ninety-nine, soon the boiler will break. Our life is at stake. More is at stake, our fatherland is at stake. More is at stake: our children's land is at stake."65

Even apart from the National Socialists and the communists, it appears as if less extremist intellectuals had almost been in a competition to determine who could depict the crisis in the most general and fundamental terms. The philosopher Arthur Liebert tried to find "the crisis" of his time that lay beyond all particular crises and served as their common spiritual and metaphysical source. ${ }^{66}$ One would expect a young, conservative revolutionary such as Edgar Julius Jung, who wanted to overcome the republic, to construct a connection between the "religious, cultural, judicial, and state crisis," but even the liberal feminist Gertrud Bäumer saw close correlations among the occupational, sexual, and spiritual crises of the present. ${ }^{67}$ In 1920 Hans von Hentig, who later became associate professor of law at the University of Kiel, even wanted to determine the relationship among "cosmic, biological, and social crises." 68 In these writings the crisis appeared more and more as an all-encompassing phenomenon, as a total crisis affecting all parts of the political, social, and economic life, not only in Germany, but also in the Occident and the whole world. ${ }^{69}$ To emphasize its importance, different phenomena were integrated into one total crisis that was then globalized as affecting the whole world and singularized as appearing only once in centuries or ages. The founder of the "Paneuropa" movement, Richard N. Coudenhove-Kalergi, offers an example of this globalization and singularization of the crisis. For him the ethical and political "double crisis" in which he was living was "the most severe crisis since primeval times. Only the simultaneous collapse of the ancient worldview because of Christianity and of the antique empire

\footnotetext{
${ }^{65}$ Franz Oppenheimer, Weder so-noch so. Der dritte Weg (Potsdam: Protte, 1933), 102.

${ }^{66}$ Arthur Liebert, Die geistige Krisis der Gegenwart, 2nd ed. (Berlin: Pan-Verlag Rolf Heise, 1923), 9.

${ }^{67}$ Edgar Julius Jung, "Reichsreform," Die Deutsche Rundschau 217 (1928): 101-112, 101; and Gertrud Bäumer, Die Frau in der Krisis der Kultur (Berlin: F. A. Herbig, 1926), 4. See also Wilhelm Medinger, Die internationale Diskussion über die Krise des Parlamentarismus (Vienna and Leipzig: Braumüller, 1929), 52.

${ }^{68}$ Hans von Hentig, Über den Zusammenhang von kosmischen, biologischen und sozialen Krisen (Tübingen: Mohr, 1920).

${ }^{69}$ Hans Thomas Achelis, Die Krisis als geistige Wandlung (Berlin: Trowitzsch \& Sohn, 1932), 7; Franz Oppenheimer, "Zur Soziologie von Krisenzeiten," Die Neue Rundschan 31, Halbband 2 (1920): 1125-1240, 1125; Artur Mahraun, Das jungdeutsche Manifest. Volk gegen Kaste und Geld. Sicherung des Friedens durch Neubau der Staaten (Berlin: Jungdeutscher Verlag, 1927), 78; Karl Haushofer and Kurt Trampler, Deutschlands Weg aus der Zeitenwende (Munich: Hugendubel, 1931), 7.
} 
because of the migration period [Völkerwanderung] can be compared to the crisis of the present. Yet, whereas that big turbulence was confined to Europe, today the whole world finds itself in a moral-political revolution of incalculable dimensions."70

None of these constructions of negative scenarios within a mutually exclusive dichotomy and none of these diagnoses of crises quoted above can be read as a pessimistic expectation of doom. They were formulated by intellectuals who not only left open whether and how the crises could be resolved, but were confident that they could and would be overcome, realizing a better future. Often they even saw the crises as necessary steps within the historical development before any betterment was possible. Moreover the construction of a pessimistic scenario served the additional purpose of motivating people to prevent it from happening and, thereby, making the positive outcome more likely. Therefore constructions of crises and "either-ors" were most popular among intellectuals and politicians on both extremes of the political spectrum who were highly optimistic and confident that they would be able to realize their utopian visions in the near future.

As it is well known, the Marxist theory of history assumed the necessary role of crises as accelerating steps that separated different stages of historical development from each other. After the bourgeois revolution, a final crisis of capitalism had to occur before the communist revolution would start and a classless society could be realized. Accordingly, all signs of crisis were welcomed in the party newspaper Die Rote Fahne as signs of the coming revolution. They indicated that the expected new time approached, because crises and the failure of "bourgeois" parties to provide solutions would instill the "feeling in the masses that they themselves had to find a way out of the crisis of the collapsing capitalist world."71 After the failed revolutionary attempts in the aftermath of World War I, communists saw a new revolutionary situation arising with the onset of the Great Depression. Because of the disappointed expectations that lay only ten years behind them, however, they emphasized that the coming of the revolution was not a natural process, but depended on the activity of the proletariat. "Lenin has taught us that capitalism knows no hopeless situations. But whether world capitalism will again be able to rescue itself temporarily out of the embrace of the crisis ultimately depends on the revolutionary power and organized fight of the proletarian masses."72 Independent communist intellectuals assumed a similar positive attitude toward the crisis. When Bertolt Brecht and Walter

\footnotetext{
${ }^{70}$ Nikolaus von Coudenhove-Kalergi, Krise der Weltanschauung (Vienna: Pan-Europa-Verlag, 1923), VII.

${ }^{71}$ Anonymous, “1921. Das Jahr der Entscheidung,” Die Rote Fahne, Morgenausgabe, Jan. 1, 1921.

${ }^{72}$ Paul Braun, "Am Vorabend weltgeschichtlicher Entscheidungen. Die internationalen Perspektiven des Jahres 1931," Die Rote Fahne, Jan. 1, 1931. See also Paul Braun, "Die revolutionären Perspektiven des Jahres 1930," Die Rote Fahne, Jan. 1, 1930; Anonymous, “Das Jahr
} 
Benjamin planned the founding of a new journal in 1930 and 1931, after the National Socialist electoral victories and during the Great Depression, they wanted to call it "Crisis and Critique" (Krise und Kritik). Correspondingly, its aim was to "define the crisis or to bring it about by means of critique," and for the first issue of the journal — which sadly never appeared - Brecht even suggested the title "Welcoming the Crisis" ("Die Begrüßung der Krise"). ${ }^{73}$

On the other side of the political spectrum the National Socialists saw the crisis as a necessary step toward the establishment of the Third Reich. At the beginning of 1927 Adolf Hitler explained that all negative developments and turbulences were reasons for National Socialists to be confident, because all failures of the current rulers were proofs of the "incapacity of their policies" and the "incorrectness of their fundamental ideas ... and then there is more confidence resulting from the growth of our own movement." ${ }^{74}$ Not only the National Socialists, but also all the proponents of a conservative revolution who wanted to overcome the democratic republic welcomed the signs of crisis as necessary indicators of a fundamental change. The best example of this longing for a crisis may be the journal Die Tat, which became more and more popular in the final years of the republic. ${ }^{75}$ While the frequency of the term "crisis" increased in all journals over the course of the Weimar Republic, it became the dominant mode of conceptualizing the world in Die Tat under the editorial guidance of Hans Zehrer.

In 1923 when Zehrer was still an unknown journalist at the Vossische Zeitung, he published his first important article under the title "The Crisis of Parliamentarism." "76 From this first journalistic success onward, Zehrer used the notion of "crisis" in his political analyses again and again. After becoming the leading editor of Die Tat, he elaborated this rhetorical scheme in collaboration with Ferdinand Fried who was responsible for the articles on the economy. As early as October 1928 Zehrer ironically summarized the course of town-hall meetings that took place all over the country and that deplored the present state of politics or the economy. Not ridiculing the fact that the people diagnosed crises everywhere, he suggested that they still were in delusion about the real extent of the crisis: since the state and the economy were simultaneously in

des großen Umschwungs,” Die Rote Fahne, Jan. 1, 1930; Anonymous, “1931!,” Die Rote Fahne, Jan. 1, 1931.

${ }^{73}$ Erdmut Wizisla, "Krise und Kritik (1930/31)," in Der junge Brecht. Aspekte seines Denkens und Schaffens, ed. Helmut Gier and Jürgen Hillesheim (Würzburg: Königshausen \& Neumann, 1996), 226-253.

${ }^{74}$ Adolf Hitler, “An alle Nationalsozialisten! Parteigenossen! Antisemiten!,” Völkischer Beobachter, Jan. 1, 2, and 3, 1927.

${ }^{75}$ Gangolf Hübinger, "Die Tat und der Tat-Kreis. Politische Entwürfe und intellektuelle Konstellationen," in Das konservative Intellektuellenmilieu, seine Presse und seine Netzwerke, ed. Michel Grunewald and Uwe Puschner (Bern et al.: Lang, 2003), 407-426.

${ }^{76}$ Ebbo Demant, Von Schleicher zu Springer. Hans Zehrer als politischer Publizist (Mainz: von Hase \& Koehler, 1971), 19. 
crisis, they could not help each other, and only an external solution was possible. ${ }^{77}$ Even before the onset of the Great Depression, Die Tat constructed severe crises and wished for their intensification. In January 1929, Zehrer argued that his longing for a crisis was justified because it was sometimes necessary in essential matters to wish for "need" in order to create "necessity" and change, playing with the German expressions for need and necessity: "deshalb muß man den Mut haben, in entscheidenden Dingen manchmal die Not zu wollen, um an die Not-Wendigkeit zu gelangen." 78

Despite his efforts, Zehrer still had the impression in 1929 that only a few and not the right people acknowledged the crisis of parliamentarism, but this picture changed after the onset of the Great Depression. ${ }^{79}$ "Krisis!," Horst Grüneberg asserted, was now the term that described the situation in all areas of culture. ${ }^{80}$ And in 1930 Die Tat observed with a sense of relief that the "crisis" had become socially acceptable ("hoffähig") to larger audiences: "Suddenly everybody detects the crisis of which we have been talking here for years." ${ }^{11}$ In Die Tat the rhetoric of crisis was not an intellectual reaction to economic turbulences or to actual problems of parliamentarism in the late Weimar Republic, but an already well-established frame of reference that was only confirmed by these developments, making it more plausible and attractive for growing audiences. This process, again, was observed by its editors. "In the past few months, for many people, the crisis has become almost overnight a reality that leaves no escapes." 82 Zehrer's constructions of crises, which he depicted more convincingly than most of his colleagues because he had been practicing this rhetorical scheme for years, became more plausible when the economic parameters worsened. Therefore, Die Tat became more successful once its articles resonated with the economic upheavals of the Great Depression.

As the above quotes show, extremist intellectuals and politicians on both sides of the political spectrum welcomed the crisis as an opportunity to overcome the existing order. In addition, they tried to deepen the sense of crisis by all means available to them. This was true also for the extremist parties that intensified the sense of a political crisis by their obstruction of parliamentary practice and their ridiculing and disparaging of republican symbols and rituals. ${ }^{83}$ In addition, their paramilitary forces challenged the state-monopoly on legitimate violence

\footnotetext{
${ }^{77}$ Hans Zehrer, “Zwischen zwei Revolutionen,” Die Tat 20, Halbband 2 (1928/29): 524-534, $525 f$.

${ }^{78}$ Hans Zehrer, “Achtung, junge Front! Draußenbleiben,” Die Tat 21, Halbband 1 (1929/30): 25-40, 39; Zehrer, "Zwischen zwei Revolutionen," $525 f$.

${ }^{79}$ Zehrer, "Achtung, junge Front!,” 36.

${ }^{80}$ Horst Grüneberg, "Das Ende der Wissenschaft?," Die Tat 21, Halbband 2 (1929/30): 597-608.

${ }^{81}$ tt, "Die Krise wird hoffähig," Die Tat 22, Halbband 1 (1930/31): 386-388.

${ }^{82}$ Anonymous, "Wohin treiben wir?," Die Tat 23, Halbband 1 (1930/31): 329-354, 329.

${ }^{83}$ Thomas Mergel, Parlamentarische Kultur in der Weimarer Republik. Politische Kommunikation, symbolische Politik und Öffentlichkeit im Reichstag (Düsseldorf: Droste, 2002); Gotthard Jasper, Der Schutz der
} 
and produced the very civil-war-like disorder that they themselves purported to be able to solve. ${ }^{84}$ Hence the political extremists created the crisis not only in their propagandistic rhetorical strategies, but also by means of their political practices. Even though it would be an exaggeration to reduce the crisis of Weimar Germany to their writings and actions and treat it as a mere fabrication, their contribution to the production of the crisis cannot be denied. As Reinhart Koselleck has argued, it is futile to try to separate the real crisis from intellectual critique and to determine which was first and caused the other. Rather, we have to treat them as belonging together, analyzing their mutual intricate interconnections andone may add - their relation to the practical creation of crises. ${ }^{85}$

Even though the discourses and sentiments of crisis were not products of the Great Depression, the economic problems that started in late 1929 made the established diagnoses of crises more plausible. Even liberal observers such as Felix Pinner acknowledged that in the face of the "disharmony of the capitalist system that has never appeared as strong as on this highest degree of technicalcapitalist perfection," it was not unreasonable for people to question if this was still a crisis "within the individual-capitalist system, or not rather a crisis of the individual-capitalist system" itself. ${ }^{86}$ Similarly, to a growing number of intellectuals the manifold problems and disturbances of the parliamentary system appeared not as individual phenomena with individual solutions, but became condensed into one comprehensive crisis of parliamentarism that demanded fundamental alternatives. In his analysis of the crisis of parliamentarism as an existential threat, Wilhelm Medinger, the Sudeten-German senator in the Prague Parliament, argued that parliamentarism was not sick because it was attacked from the left and the right, but it was attacked because it was sick. ${ }^{87}$ Hence, authoritarian models became more and more attractive not only in Germany, but also in other countries.

Despite the fact that the economic and political developments in the final years of the Weimar Republic enhanced the plausibility and attractivity of the notion of "crisis," the reference to these processes cannot explain the ubiquitous use of the term. At least, the economic bust and the political problems are not sufficient to

Republik. Studien zur staatlichen Sicherung der Demokratie in der Weimarer Republik, 1922-1930 (Tübingen: Mohr, 1963).

${ }^{84}$ For recent syntheses, see Dirk Schumann, Political Violence in the Weimar Republic: 1918-1933. Fight for the Streets and Fear of Civil War (New York: Berghahn, 2009); Dirk Blasius, Weimars Ende. Bürgerkrieg und Politik 1930-1933 (Göttingen: Vandenhoeck \& Ruprecht, 2005).

${ }^{85}$ Reinhart Koselleck, Kritik und Krise. Eine Studie zur Pathogenese der bürgerlichen Welt, 6th ed. (Frankfurt am Main: Suhrkamp, 1989), 1.

${ }^{86}$ Felix Pinner, "In dritter Potenz. Deutsche Sonderkrise-Weltkrise-Politische Krise," Berliner Tagblatt und Handels-Zeitung, 9. Beiblatt, Jan. 1, 1931.

${ }^{87}$ Medinger, Die internationale Diskussion über die Krise des Parlamentarismus, 4. See also Willy Hellpach, Die Krisis des deutschen Parlamentarismus. Vorträge auf der Tagung deutscher Hochschullehrer 1927 (Karlsruhe: Braun, 1927), 3. 
explain the formation of the discourses about crises, and they cannot illuminate their interesting aspects and concrete structures. We cannot determine a causal chain for any of the above quoted diagnoses of crisis from the occurrence of certain phenomena in the external world-whether in the field of politics, economics, or society - toward an experience of these as critical, the formulation of a "crisis," and the development of certain reactions. Taking into consideration the intrinsically prognostic dimension of the concept, it becomes clear why this could not even be the case: the economic, political, and social developments were perceived from various standpoints, particularly in the light of different visions of the future that defined whether and how the present was experienced as a crisis. ${ }^{8} 8$

With respect to the Great Depression, one must at least distinguish among socialist, nationalist, internationalist, and moral or spiritual understandings of the crisis. None of the economic indicators decided conclusively whether present developments were to be understood as the last great crisis before the final breakdown of capitalism, as the product of moral decay and secularization, as caused by the lack of an international economic order, or as a consequence of too much international integration of the economies. ${ }^{89}$ These were very different diagnoses of crisis, all of which had high currency in different parts of the political spectrum. Their heterogeneity resulted from the differing normative ideals of historical development and visions of society, economy, and the state. Those visions, against which the present looked comparatively bleak, decided what was perceived as a crisis and which strategies of action were needed to overcome it. The same economic developments were used to justify socialization and the communist revolution, the establishment of national autarky, a community of European states, or moral and spiritual renewal. ${ }^{90}$ Since the perceived crises were as different as the mental outlooks and the plans of action, we cannot point at the crisis of Weimar Germany to explain the visions or the activities.

\footnotetext{
${ }^{88}$ Graf, "Die 'Krise' im intellektuellen Zukunftsdiskurs der Weimarer Republik," 92-99.

${ }^{89}$ As examples of the different interpretations, see Ernst Thälmann, "Volksrevolution über Deutschland. Rede auf dem Plenum des ZK. der KPD. 15.-17. Januar 1931" (Düsseldorf: Westdeutsche Buchdruckwerkstätten AG, 1931), 19f.; Carl Steuermann (Pseudonym of Otto Rühle), "Der Mensch auf der Flucht," Die Neue Rundschau 43, Halbband 1 (1932): 289-300, 291; Alfred Braunthal, Die Wirtschaftskrise. Krisenursachen, Krisenverlauf, Krisenüberwindung (BerlinFriedenau: Werk und Wirtschaft, 1933); Hans Zehrer, "Der Sinn der Krise," Die Tat 23, Halbband 2 (1931/32): 937-957, 941f.; Ferdinand Fried, “Die Krise des Kapitalismus," Die Tat 22, Halbband 1 (1930/31): 89-112; Hans Thomas, Die Krisis als geistige Wandlung (Berlin: Trowitzsch \& Sohn, 1932), 7-9; Rudolf Bultmann, Krisis des Glaubens. Krisis der Kirche. Krisis der Religion. Drei Marburger Vorträge (Gießen: Töpelmann, 1931).

${ }^{90}$ Ferdinand Fried, Autarkie (Jena: Eugen Diederichs, 1932); Wilhelm von Kries, "Zur Pathologie der Wirtschaftskrise," Deutsche Rundschau 229 (1931): 1-6; Anonymous, “Sturmjahr 1932,” Die Rote Fahne, Jan. 1, 1932; Alfred Weber, "Deutschland und die europäische Kulturkrise," Neue Rundschau 35, Halbband 1 (1924): 308-321; Richard N. Coudenhove-Kalergi, "Krise der Weltanschauung," Die Neue Rundschau 35, Halbband 1 (1924): 28-41; Moritz Julius Bonn, Die Krisis der europäischen Demokratie (Karlsruhe: Braun, 1925), esp. 127-140; Achelis, Die Krise als geistige Wandlung.
} 


\section{Conclusion}

Since crises are narrative structures that transform a complex world into a dramatic plot, it is tempting for historians to adopt historical diagnoses of crises to structure their own narratives. Yet, because of the narrative structure of crises, necessarily binding the notion to an observer, this procedure can easily lead to false conclusions. To begin with, as the considerations above have shown, contemporaries in Weimar Germany did not use "crisis" in the sense of deterioration or doom in which the term has often been used in historiography depicting Weimar as the prelude to National Socialism. By positioning themselves in a period of crisis, Weimar intellectuals and politicians conceptualized the present as a time of decision between two mutually exclusive, existential alternatives to motivate other people to bring about the desired option and prevent the undesired. Extremist political forces in particular saw crises everywhere and integrated them into one big, comprehensive crisis to justify their radical strategies of action. Their plans and actions, they were confident, would overcome the crisis which, in their highly optimistic schemes, was only a step toward fundamental betterment. Because of this instrumental use of "crisis" in Weimar political discourse, crises cannot be easily transferred into historical scholarship as causal factors that brought about social, political, or intellectual changes. Rather Weimar's crises should be understood as the products of the people who diagnosed them and not as factors that can be used in explanations of Weimar's collapse. In other words, historical analyses should not end by pointing at the crisis, but rather start from there.

This change of perspective can, in turn, contribute to a better understanding of Weimar political debates and culture. Even if it is too superficial simply to turn the diagnosed crises into the causes of the republic's destruction, the constructions of crises still were important factors in this respect. The obsession by contemporaries with the notion of "crisis" and the exclusive "either-or," as well as the concurring and ever more radical constructions of crises, contributed to the sense of a loss of options: increasingly, all political opportunities seemed to narrow to one basic alternative. Moreover, the notion of crisis raised the stakes in the political debates and increased their existential dimension..$^{91}$ The globalization and singularization of the crisis particularly changed the perception of politics from a recursive business in which decisions could be made and if false, corrected, to a conception of the present as a fateful time in which irreversible decisions had to be made that affected the whole world and all future generations. Diagnoses of crises dramatized the present, and historians must analyze these processes: Who tried to gain intellectual hegemony by depicting the present as a time of

\footnotetext{
${ }^{91}$ George W. Wallis, "Chronopolitics: The Impact of Time Perspectives on the Dynamics of Change," Social Forces 49 (1970): 102-108, 105.
} 
an exclusive "either-or," following what interests and pursuing what goals for the future? Which diagnoses were more successful than others, and why was that the case? In other words, we should neither treat historical diagnoses of crises as simple depictions of a dramatic past, nor adopt them into our own historical narratives. Rather, their contribution to the dramatization of the past has to be at the center of historiographical analysis.

RUHR-UNIVERSITy BOCHUM 